\title{
不確定需要を考慮した施設配置問題
}

$\begin{array}{llllll}\text { 正員 } & \text { 西 田 直 矩 (東京理科大) } \\ \text { 非会員 桧 坦 正 浩 (東京理科大) } \\ \text { 非会員 馬 㴊 } & & \text { 透 (東京理科大) }\end{array}$

\section{The Facility Location Problem under Demand Uncertainty}

Naonori Nishida, Member, Masahiro Higaki, Non-member, Mabuchi Tooru, Non-member

(Science University of Tokyo)

The facility location problem is one of the well-studied combinatorial optimization problems, and a number of algorithms which could find the optimal solution efficiently have been proposed. The facility location problem which considers the parametrjc analysis on demands has been studied, and this problem can handle the demand uncertainty to some extent. This paper deals with the facility location problem in which the customer's demands are given by the probability distribution functions. This model can provide more realistic information than the parametric analysis.

Firstly, the facility location problem under demand uncertainty is formulated as a mixed integer programming problem. The objective function to be minimized is the expected value of the total cost. To prevent the algorithm from finding such solutions that are very unlikely to satisfy the demand, a constraint is imposed so as to satisfy the total demand with more than a given probability. A branch-and-bound algorithm is proposed to find the exact solution. To find the optimal solution efficiently, a procedure for calculating the lower bound is presented. Moreover, to strengthen the lower bound, the Lagrangean relaxation is applied for the constraints on demand. Lastly, to illustrate the efficiency of the proposed method, the computational experience is given.

キーワート゚ : 施設配置問題, 混合整数計画問題, 確率計画問題

\section{1.はじめに}

幾つかの供給施設の建設候補地と需要地があり，供 給地から需要地の需要量を満たすように製品を翰送す るとき，施設の建設にかかる固定費と，輸送費の和の 総費用を最小にするような建設方法を決定する問題が 施設配置問題である。この問題は混合整数計画問題の 代表的な問題であり，最適解を効率良く探索するいる いろな解法テクニックが研究されている(1) (5)。また, 多重選択制約付き施設配置問題と言われる一建設候補 地に対し複数の規模加ら建設施設を選択可能な問 題(6)，需要量のバラメトリックな変化を考慮した問 題(7)などが研究されている。

本論文で扱う施設配置問題は以下のようである。従
来の施設配置問題の定式化では, 需要量は確定値とし て与える必要がある。しかし現実には，需要量にばら つきがある問題の解が要求されることが多い(8)c需要 量の分布において，一部には相関がある分布なども考 充られるが，本モデルでは，相関に関保なく任意の分 布を考慮できる。

また，「絶対に需要を満たす条件」を設定すると， 需要量のばらつきを考えたときに, 不必要に巨大な施 設の建設をする解が発生する。この防止の制約とし て, 総供給量が, 総需要量を例えば, $99 \%$ 以上の確 率で満たすことを本定式化では制約として加えて いる。

その他，総賸用に制限があり，その制限の超過にペ ナルティーが存在する問題も本アルゴリズムでは解く 
ことができる。これは，確率計画法における上方向の 分散の評価を近似的に考えたものである。

いろいろな問題の設定を考慮できるため，問題が複 雑化しているように考えられるが，どれも現実に要求 されている制約である。本アルゴリズムの対象とする 問題の特徴を以下にまとめて示す。

（1）需要量に任意の分布を想定できる。

（2）総需要を満たす確率の条件を考慮できる。

（3）総費用の制限のペナルティーを設定できる。

単純な構造をもつ施設配置問題に対する解法 ${ }^{(9)} や$, 需要量以外のパラメータに不確定性を含んだ問題に対 する解法 ${ }^{(10)(11)}$ な゙は研究されているが，本問題はこ れらと異なった問題である。

\section{2. 不確定需要を考慮した施設配置問題}

不確定需要を考慮した施設配置問題の定式化を 行う。

$m$ 個の建設予定地 $i(i=1,2, \cdots, m)$ が存在し, そ

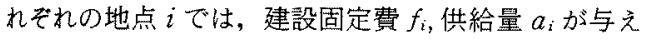
られている。また，需要地 $j(j=1,2, \cdots, n)$ があり， 需要地 $j$ の需要量は $\theta_{j}$ である。また, 建設候補地 $i$ 加管要地 $j$ 人製品 1 単位輸送するときにかかる輸送 費用 $c_{i j}$ が与えられている。

ここで, 需要量の分布を表現するために, $\theta_{\mathbf{l}}, \cdots, \theta_{n}$ の確率密度関数を $F\left(\theta_{1}, \theta_{2}, \cdots, \theta_{n}\right)$ とする。この関数 は, 需要地 $j$ の需要が $\theta_{j} \sim \theta_{j}+d \theta_{j}(j=1, \cdots, n)$ となる 同時確率が,

$$
F\left(\theta_{1}, \cdots, \theta_{n}\right) d \theta_{1} \cdots d \theta_{n}
$$

となることを表している。Fは確率密度関数より， 次式が成立する。

$$
\begin{aligned}
& \int_{D} F\left(\theta_{1}, \cdots, \theta_{n}\right) d \theta_{1} \cdots d \theta_{n}=1 \cdots \cdots \cdots \cdots \cdots \\
& D=\left\{\left(\theta_{1}, \cdots, \theta_{n}\right) \mid \gamma_{j} \leqq \theta_{j} \leqq s_{j}, j=1, \cdots, n\right\}
\end{aligned}
$$

(3)式の領域 $D$ は需要量の有界な領域を示し,下 限を $r_{j}$, 上限を $s_{j}$ とする。また，以後の説明のため， $\theta=\left(\theta_{1}, \cdots, \theta_{n}\right)$ とおく。

需要量 $\theta_{1}, \cdots, \theta_{n}$ がす心゙て独立な確率変数ならば, 関数 $F$ は, 各々の需要地 $j の$ 需要の確率密度関数の 積の形となるが，一般に相関のある分布を想定してお く。現実には，需要地の需要量間に相関の高い場合が 多いと考えられる。

すべての需要地において，その需要を満たし，輸送 費用と施設の建設国定費の総和の期待值を最小にする 建設地点を求めるのが目的である。ここで, 輸送方法 については，実際の需要が決定してから輸送問題を解
いて求めるのが良い。パラメトリック問題と異なり, 以後の議論において, 建設地点が, 需要量のパラメー 夕の関数ではなく, 領域 $D$ に対し, 最も有利な一つ の建設方法を求めるのが目的であることに注意が必要 であり，このような解を求めることができるのが，本 アルゴリズムの特徴である。

建設候補地 $i$ に施設を建設するかどうかの0-1変数 を $y_{i}$, 建設候補地 $i$ 別需要地 $j$ への輸送量を $x_{i j}$ す ると, 不確定需要を考慮した施設配置問題は問題 $P_{0}$ のように定式化できる。

間題 $P_{0}$ :

$$
\begin{aligned}
& \min _{y} V(y) \\
& \text { s. t. } \sum_{i=1}^{m} a_{i} y_{i} \geqq S(\alpha) \\
& y_{i} \in\{0,1\} \quad(i=1, \cdots, m)
\end{aligned}
$$

ただし， $V(y)$ は建設方法 $y$ ○きの費用の期待值で ある。また，ベクトル $y=\left(y_{1}, \cdots, y_{m}\right)$ である。

$$
\begin{aligned}
V(y)= & \int_{D}\left\{T \left(\min _{x} \sum_{i=1}^{m} \sum_{j=1}^{n} c_{i j} x_{i j}\right.\right. \\
& \left.\left.+\sum_{i=1}^{m} f_{i} y_{i}\right) F(\theta)\right\} d \theta_{1} \cdots d \theta_{n}
\end{aligned}
$$

s. t. $\sum_{j=1}^{n} x_{i j} \leqq a_{i} y_{i} \quad(i=1, \cdots, m)$

$\sum_{i=1}^{m} x_{i j} \geqq b_{j}(\theta) \quad(j=1, \cdots, n)$

$x_{i j} \geqq 0 \quad(i=1, \cdots, m ; j=1, \cdots, n)$

ただし，ベクトル $x=\left(x_{11}, \cdots, x_{m n}\right)$ である。（9)式の $b_{j}(\theta)$ は見掛けの需要唓を表し,

$$
\begin{aligned}
& \left(\sum_{i=1}^{m} a_{i} y_{i} \geqq \sum_{j=1}^{n} \theta_{j}\right) \text { のとき, } \\
& b_{j}(\theta)=\theta_{j} \\
& \left(\sum_{i=1}^{m} a_{i} y_{i}<\sum_{j=1}^{n} \theta_{j}\right) \text { のさ, } \\
& b_{j}(\theta)=\left(\sum_{i=1}^{m} a_{i} y_{i}\right) \frac{\theta_{j}}{\sum_{j=1}^{n} \theta_{j}}
\end{aligned}
$$

(4)〜(6)式は, 変数 $y$ の制約のもとで, 総費用 の期待值の最小となる施設の建設方法 $y$ を求める問 題である。（4）式は総費用の期待値の最小化を表す目 的関数，(5)式は総供給量を $\alpha$ 以上の確率で満たす 制約である。ここで, $S(\alpha)$ は $F(\theta)$ から求まる定数 であり，以下のように求めることができる。任意の分 布に対して $S(\alpha)$ は，数㒹積分などを使って求めるこ とができる。

まず, 需要量の和 $\eta=\sum_{j=1}^{n} \theta_{j}$ の分布の確率密度関 数は, 


$$
\begin{aligned}
& G(\eta)=\int_{D^{\prime}(\eta)} F(\theta) d \theta_{1} \cdots d \theta_{n} \\
& D^{\prime}(\eta)=\left\{\theta \mid \theta \in D, \eta=\sum_{j=1}^{n} \theta_{j}\right\}
\end{aligned}
$$

となるので,

$$
\int_{\left(\sum_{i=1}^{n} r_{i}\right)}^{S(\alpha)} G(\eta) d \eta=\alpha
$$

（6）式は建設決定変数 $y_{i}$ の 0-1 整数条件，（7）式 は，建設方法yであるときの総費用の期待值である。 ここで，総費用制限関数 $T$ について述べる。

この関数 $T$ は，総費用の制限を超えた場合に付加 するペナルティー（罰則）を与える関数であり，ある 総費用の上限 $\mu$ を超えるとペナルティー $M(M>0)$ が加加る次の上うな関数とする。この関数の導入によ り，総費用が上限を超える確率の高い解を減らすこと

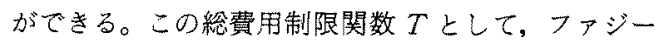
関数を定義することも可能であるが，本論文に扔ける 定式化では(16)式のように定義しておく。

$$
T(c)= \begin{cases}c & (c \leqq \mu) \\ c+M & (c>\mu)\end{cases}
$$

(8) （10)式は，(7)式の（）内の $x$ に関する最 小化問題の制約条件，(8)式は供給地に扔ける供給上 限制約，(9)式は需要地における需要制約であり, (10)式は，輸送䍛の非負制約である。

現実に合うように，問題において次の仮定をして 扔く。

$$
\begin{aligned}
& a_{i}>0, f_{i} \geqq 0 \quad(i=1, \cdots, m) \\
& c_{i j} \geqq 0 \quad(i=1, \cdots, m ; j=1, \cdots, n) \\
& r_{j}>0, s_{j} \geqq r_{j} \quad(j=1, \cdots, n) \cdots \cdots \cdots
\end{aligned}
$$

(12)式は，需要を満たすことができない領域での需 要量の定数である。(5)式で示したように， $\alpha$ 以上の 確率で総供給量は総需要量を満たすが，その残りの領 域で目的関数值を定義しなければならない。(12)式 は，現実にみら机るように，「供給量の不足分を各々 の需要量に比例して分配する」という考元方に基づい ている。式では，これと同値な「供給量を各々の需要 量に比例して分配する」ことに表現している。

\section{3. 解法アルゴリズム}

〈3・1〉 下界值計算 本問題に対して，ここでは 分枝限定法に基づいたアルゴリズムを提案する。

まず，下界値の計算のために，0-1 整数条件 $(6)$ 式 を，連線緩和する。分枝限定木上の任意の問題に対す る緩和問題仿, 問題 $P_{1}$ のようになる。

$L_{0}$ : 分枝によって, $y_{i}=0$ に固定された施設建設候 補地の集合。
$L_{1}$ ：分枝によって, $y_{i}=1$ に固定された施設建設候 補地の集合。

$L_{2}$ : まだ固定されていない施設建設候補地の集合。 $L_{0} U L_{1} U L_{2}=\{1, \cdots, m\}$

問題 $P_{1}$ :

$$
\begin{aligned}
& \min _{y} \int_{D}\left\{T \left(\min _{x} \sum_{i \in L_{1} \cup L_{2}} \sum_{j=1}^{n} c_{i j} x_{i j}\right.\right. \\
& \left.\left.+\sum_{i \in L_{2}} f_{i} y_{i}+\sum_{i \in L_{1}} f_{1}\right) F(\theta)\right\} d \theta_{1} \cdots d \theta_{n} \\
& \text { s. t. } \sum_{i \in L_{2}} a_{i} y_{i}+\sum_{i \in L_{1}} a_{i} \geqq S(\alpha) \\
& 0 \leqq y_{i} \leqq 1 \quad\left(i \in L_{2}\right) \\
& \sum_{j=1}^{n} x_{i j} \leqq a_{i} y_{i} \quad\left(i \in L_{2}\right) \\
& \sum_{j=1}^{n} x_{i j} \leqq a_{i} \quad\left(i \in L_{1}\right) \\
& \sum_{i \in L_{1} U L_{2}} x_{i j} \geqq b_{j}(\theta) \quad(j=1, \cdots, n) \\
& x_{i j} \geqq 0 \quad\left(i \in L_{1} U L_{2} ; j=1, \cdots, n\right)
\end{aligned}
$$

ここで, $y$ は $\theta$ の関数ではない。しかし, $x$ と $y$ を独立に解くのは困難である。このため, 問題を緩和 し, $y$ を $\theta$ の関数となることを許し，下界値とする。 制約 (21)のため, 既往の研究の方法で洁, 変数y を消去できない。しかし，問題 $P_{1}$ をLPで解くの は, 効率が悪い。(23), (24) 式に対し, スラック变数 $x_{i, n+1}\left(i \in L_{1} U L_{2}\right)$ を考元る。

$$
\begin{aligned}
& \sum_{j=1}^{n+1} x_{i j}=a_{i} y_{i} \quad\left(i \in L_{2}\right) \\
& \sum_{j=1}^{n+1} x_{i j}=a_{i} \quad\left(i \in L_{1}\right)
\end{aligned}
$$

ここで，(27)式を用いて変数 $y$ を消去する。また， $c_{i, n+1}=0\left(i \in L_{1} U L_{2}\right)$ としておくと, 等価な問題 $P_{2}$ に 変換できる。これは,パラメトリック輸送問題を含 み，その目的関数値を重み付きで重積分を計算する問 題である。

問題 $P_{2}$ :

$$
\begin{aligned}
& \int_{D}\left\{T\left(\min _{x} \sum_{i \in L_{1} U L_{2}} \sum_{j=1}^{n+1} c_{i j}^{\prime} x_{i j}+\sum_{i \in L_{1}} f_{i}\right)\right. \\
& \quad \times F(\theta)\} d \theta_{1} \cdots d \theta_{N} \quad \cdots \cdots \cdots \cdots \cdots \cdots \cdots \\
& \text { s.t. } \sum_{j=1}^{n+1} x_{i j} \leqq a_{i} \quad\left(i \in L_{1} U L_{2}\right) \quad \cdots \cdots \cdots \cdots \\
& \sum_{i \in L_{1} U L_{2}} x_{i j} \geqq b_{j}(\theta) \quad(j=1, \cdots, n+1) \cdots \cdots \\
& x_{i j} \geqq 0 \quad\left(i \in L_{1} U L_{2} ; j=1, \cdots, n+1\right) \cdots \\
& c_{i j}^{\prime}=\left\{\begin{array}{ll}
c_{i j} & \left(i \in L_{1}\right) \\
c_{i j}+f_{i} / a_{i} & \left(i \in L_{2}\right)
\end{array}\right) \cdots \cdots \cdots \cdots \cdots . .
\end{aligned}
$$$$
\text { ただし， }
$$ 


$$
b_{n+1}(\theta)=S(\alpha)-\sum_{j=1}^{n} \theta_{j}
$$

(34)式は，(21)式と等価な条件を需要量で表現した 式である。

パラメータ $\theta$ の值によって, 三つの状態に分けて 考える。

$$
\begin{aligned}
& \text { フェイズ } 1: \\
& S(\alpha)>\sum_{j=1}^{n} \theta_{j}
\end{aligned}
$$

(34)式は有効であり，仮想需要地 $n+1$ が必要。 フェイズ2:

$$
S(\alpha) \leqq \sum_{j=1}^{n} \theta_{j} \leqq \sum_{i \in L_{i} \cup L_{2}} a_{i}
$$

需要量の制約により，S( $\alpha)$ が保証された状態であ $\eta, \theta_{n+1} \leqq 0$ となり，仮想需要地 $n+1$ は必要ない。 フェイズ 3 :

$$
\sum_{i \in L_{1} \cup L_{2}} a_{i}<\sum_{j=1}^{n} \theta_{j}
$$

建設候補地のすべての施設を建設しても総需要量を 満たさない状態であり, 残り $(1-\alpha)$ の領域で発生す る。パラメトリック輸送問題を解く過程において, 発 生する問題である。

現実の問題では施設を建設した後に，需要量が予想 以上に大きかったときに対応して考えることができ る。仮定より，このような状態が $(1-\alpha)$ 末満の確率 で発生する。塞際，このようなときには，一部の需要 地がこの供給不足の影䇾を受けるのではなく，不足分 をすべての需要地に比例分配し，すべての需要地で少 しずつ需要を満たさないように輸送されるであるう。 この処置を式で表す。不足量は次のようになる。

$$
\sum_{j=1}^{n} \theta_{j}-\sum_{i \in L_{1} U L_{2}} a_{i}
$$

この不足分をすべての需要地に，需要量に比例して 分毁するので，需要地jの需要量は次の式て与えら れる。

$$
\begin{aligned}
\theta_{j} & -\left(\sum_{j=1}^{n} \theta_{j}-\sum_{i \in L_{1} u L_{2}} a_{i}\right) \cdot \theta_{j} / \sum_{j=1}^{n} \theta_{j} \\
= & \sum_{i \in L_{1} \cup L_{2}} a_{i} \cdot \theta_{j} / \sum_{j=1}^{n} \theta_{j}=b_{j}(\theta) \cdots
\end{aligned}
$$

このように，比例配分すると非線形なパラメトリッ ク輸送問題（特殊な非線形なので，線形問題に噜普で

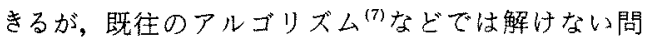
題）を解く必要がある。問題 $P_{1}$ をLPなどで解くな らば，制約 (38)はそれほど複雑ではないが，この(1 一）の領域のために，演算時間を費やすのは，むた である。もし，この問題を正確に解くと，「すべての 需要地において，需要を満たす解率は $\alpha$ 以上である(合
計で $\alpha$ 以上の確率で満たすのよりも強力な制約)」 と説明できる。

$$
\begin{aligned}
& \text { フェイズ } 2 \text { (フェイズ1）の需要の限界である。 } \\
& \sum_{j=1}^{n} \theta_{j}=\sum_{i \in L_{1} U L_{2}} a_{i}
\end{aligned}
$$

となったときの輸送方法 $x$ て残りの確率 $(1-\alpha)$ 末満 で起こる領域（供給不足の領域）にお打る輸送方法と する。

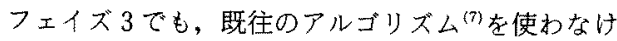
れば， $P_{2}$ の目的関数たけは簡単に計算できるが， $\theta$ の関数となる变数 $x$ が求まらない。

nパラメータの場合は近似を行うので，(38)式は簡 単に考慮できる。

問題 $P_{2}$ の目的関数值を求めるためには，需要量に nパラメータあるパラメトリック輸送問題を解かなけ ればならない。

多次元のパラメータをもつパラメトリック問題の解

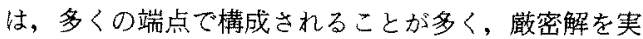
用的な時間内に求めるのは困難であり，ばらつきを仮 定する元問題の性質から厳密解を求める必要性もな い。このため, 需要量間に強い相関か存在し, 需要量 が 1 パラメータで表現できる以外は, 問題 $P_{2}$ の目的 関数の近似値を計算することにより，元問題を高速に 実用的な時間内に解くことを考える。1パラメータ. 複数パラメータの場合に分けて, 解法アルゴリズムを 述べる。

〈3・2〉需要量が1パラメータで表現できる場合の 下界値計算需要量のばらつきは, 各需要地に扔い て相関をもつ場合が多い。ここで，需要のばらつき が，ほとんど1パラメータで説明できる場合，つまり $\theta_{1}, \cdots, \theta_{n}$ の相関が高く，1 パラメータで近似できる 場合を考え，定数 $\rho_{j}, \tau_{j}$,パラメータ又を用いて $\theta_{j} \fallingdotseq$ $\rho_{j} \chi+\tau_{j}(j=1, \cdots, n+1)$ と表現できるとすると, 解か なければならない問題は，P P 新のうになる。

問題 $P_{3}$ :

$$
\begin{aligned}
& z(\chi)=\min \sum_{i \in L_{1} U_{2}} \sum_{j=1}^{n+1} c_{i j}^{\prime} x_{i j} \quad \cdots \cdots \cdots \cdots \cdots \\
& \text { s.t. } \sum_{j=1}^{n+1} x_{i j} \leqq a_{i} \quad\left(i \in L_{1} U L_{2}\right) \quad \cdots \cdots \cdots \cdots \\
& \sum_{i \in L_{1} U L_{2}} x_{i j} \geqq \rho_{j} \chi+\tau_{j} \quad(j=1, \cdots, n+1) \cdots \\
& x_{i j} \geqq 0\left(i \in L_{1} U L_{2} ; j=1, \cdots, n+1\right) \cdots \cdots
\end{aligned}
$$

ここで, 問題 $P_{0}$ の定義, $(34)$ より, $\theta$ の範团, $\theta$ と $\chi の$ 関係式より，次の関倸が成立する。

$0 \leqq \chi \leqq 1$

$\min \left(\tau_{j}, \rho_{j}+\tau_{j}\right)=r_{j}$, $\max \left(\tau_{j}, \rho_{j}+\tau_{j}\right)=s_{j} \quad(j=1, \cdots, n)$ 


$$
\rho_{n+1}=-\sum_{j=1}^{n} \rho_{j}, \tau_{n+1}=S(\alpha)-\sum_{j=1}^{n} \tau_{j}
$$

問題 $P_{3}$ は, パラメトリック輸送問題の解法アルゴ リズムで解くことができる。

\section{〈3.3〉 複数パラメータの場合の下界值計算}

前述のように, 需要量が複数パラメータで変化する 場合, 問題 $P_{2}$ を綮密沉解くのは, 困難である。定式 化は，現実問題を表現できるように工夫されているた め, 現実規模の問題の近似解でも求めることが切望さ れる。このため, 問題 $P_{2}$ の近似解を求めることを考 える。

需要地が $n$ 個存在し, 需要量パラメータが $n$ 個存 在しても，実際はnパラメータではなく，より少な いパラメータで表現（または，近似）できる場合が多 い。このため, 演算時間の高速化のため, $n$ 個の需要 量は, $n^{\prime}$ 個 $\left(n \geqq n^{\prime}\right)$ のパラメータで近似できるとし て打く。この $n^{\prime}$ 個の変数決定は, 多変量統計解析の 主成分分析の考方方を用いて求めることができるが， 問題のモデル化のとき問題 $P_{3}$ のように定式化するこ

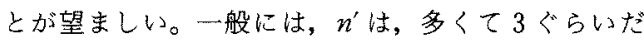
と思われる。

定数 $n^{\prime}, \rho_{j k}, \tau_{j k}$ を用いて $\theta_{j} \fallingdotseq \sum_{k=1}^{n^{\prime}} \rho_{j k} \theta_{k}^{\prime}+\tau_{j k}(j=1, \cdots$, $n+1)$ と表現できるとすると問題 $P_{2}$ は次の問題を解 き，重積分を計算することにより求めることがで きる。

問題 $P_{4}$ :

$$
\begin{aligned}
& z\left(\theta^{\prime}\right)=\min _{x} \sum_{i \in L_{i} U L_{2}} \sum_{j=1}^{n} c_{i j}^{\prime} x_{i j} \quad \cdots \cdots \cdots \cdots \cdots(43) \\
& \text { s.t. } \sum_{j=1}^{n+1} x_{i j} \leqq a_{i} \quad\left(i \in L_{1} U L_{2}\right) \quad \cdots \cdots \cdots \cdots(44) \\
& \sum_{i \in L_{1} U L_{2}} x_{i j} \geqq \sum_{k=1}^{n^{\prime}} \rho_{j k} \theta_{k}^{\prime}+\tau_{j k} \quad(j=1, \cdots, n+1) \\
& \cdots \cdots \cdots \cdots \cdots \cdots \cdots \cdots \cdots \cdots(45) \\
& x_{i j} \geqq 0 \quad\left(i \in L_{1} U L_{2} ; j=1, \cdots, n+1\right) \cdots(46
\end{aligned}
$$

問題 $P_{4}$ の目的関数値は, $n^{\prime}+1$ 次元空閒で考元る ことができる。 $\theta^{\prime}$ の空間の点 $w^{n^{\prime}}$ 個を用いた凸多面 体で $P_{4}$ のパラメトリックな解を近似する。この状態 を図で表現したのが，図1，図2である。説明のた め, $w=5, n^{\prime}=1$ としているが,この近似は，一般に $n^{\prime} \geqq 2$ のための近似アルゴりズムである。

明ら加に, 計算方式 1 は, 目的関数 $z\left(\theta^{\prime}\right)$ 上りも大 きくなる性質をもつ。 $z\left(\theta^{\prime}\right)$ の近似としては，計算方 式1のほうが良いと思われるが，ここで求めるべき值 は，(29)式の積分値であるので，計算方式 1, 計算方 式 2 の優劣峙明白ではない。1パラメータの場合の図 1, 図 2 のように, どちらの計算量もあまり変わらな

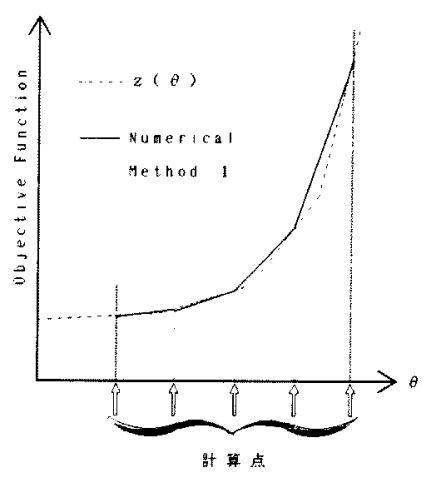

図 1 計算方式 1

Fig. 1. Numerical Method 1.

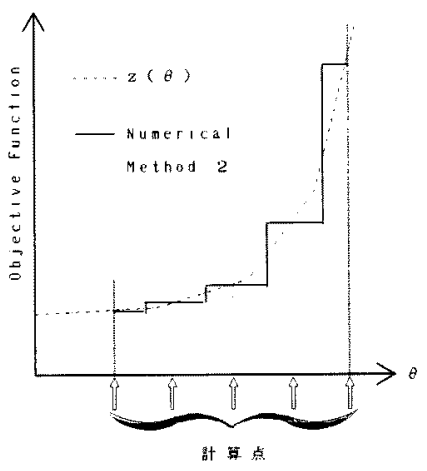

図 2 計算方式 2

Fig. 2. Numerical Method 2.

いが，2 パラメータ以上になると，計算方式 1 のほう は，重積分を各 $\theta^{\prime}$ 軸に平行な方向だけで積分できな い。 $\left(n^{\prime}=1\right.$ の場合, 積分領域は, 線分だが， $n^{\prime}=2$ の 場合は，多角形となるため，計算が複雑になる)。

ここで生成される输送問題は, 再最適化によって解 くことができる。数值実験では，アウトオブキルタア ルゴリズムを輸送問題用に調整したアルゴリズムによ って解いている。

以上のことから，計算方式 1 ををりに使う理由もな い。このため, 計算方式 $2 て ゙ n^{\prime}$ 次のパラメトリック 問題 $P_{4}$ の目的関数 $z\left(\theta^{\prime}\right)$ を近似する。

本アルゴリズムを適用した演算時間は, 不定積分 か, 数値積分の選択によって大きく影響を受ける。こ の点においても計算方式 2 が有利である。

〈3.4〉 下界值の強化と分枝方法 問題 $P_{0}$ の需要 制約 $(9)$ 式をラグランジュ緩和し, 総費用制限関数 $T$ を無視し，次のような問題を考える。総費用制限 
関数 $T$ をペナルティー計算に用いたほうが良いが， 困難な問題となる。

しかし、ここでは，前節で考虑できなかった需要墨 パラメータ $\theta$ に依存しない施設の整数条件付きの一 つの建設計画 $y$ を求めることができる。前節の $y$ が $\theta$ の関数になることによって，どのくらい下界值が悪 化するかを評価するのは難しいが，本節で考える問題 では，この点において，下界值を強化できる可能性を 十分含んでいる。

問題 $P_{5}$ :

$$
\begin{aligned}
& \min _{y} \int_{D}\left\{\min _{x} \sum_{i=1}^{m} \sum_{j=1}^{n} c_{i j} x_{i j}+\sum_{i=1}^{m} f_{i} y_{i}\right. \\
& \left.+\sum_{j=1}^{n} s_{j}(\theta)\left(b_{j}(\theta)-\sum_{i=1}^{m} x_{i j}\right)\right\} F(\theta) \\
& \times d \theta_{1} \cdots d \theta_{n} \\
& \text { s. t. } \sum_{j=1}^{n} x_{i j} \leqq a_{i} y_{i} \quad(i=1, \cdots, m) \\
& \sum_{i=1}^{m} a_{i} y_{i} \geqq S(\alpha) \\
& 0 \leqq x_{i j} \leqq b_{j}(\theta) \quad(i=1, \cdots, m ; j=1, \cdots, n) \\
& y_{i} \in\{0,1\} \quad(i=1, \cdots, m)
\end{aligned}
$$

(50) 式は，（9）式から導かれる実行可能解の必要条 件である。

$s_{j}(\theta) を(9)$ 式に対する双対変数と扔く。ここで, $s_{j}(\theta)$ は，明記しているように， $\theta$ の関数であること に注意が必要であり，また， $b_{j}(\theta)$ は，(11)，(12)式 よりyの関数でもある。

$x_{i j}$ と $y_{i}$ を独立に処理できるように変形する。ま

ず，(50)式を次のように緩和する。

$0 \leqq x_{i j} \leqq \theta_{j}$

次に，(47)式変形する。

$$
\begin{aligned}
& \min _{y} \int_{D}\left\{\min _{x} \sum_{i=1}^{m} \sum_{j=1}^{n}\left(c_{i j}-s_{j}(\theta)\right) x_{i j}\right. \\
& \left.\quad+\sum_{i=1}^{m} f_{i} y_{i}+\sum_{j=1}^{n} s_{j}(\theta) b_{j}(\theta)\right\} F(\theta) d \theta_{1} \cdots d \theta_{n}
\end{aligned}
$$

ここで，第1項に注目し，

$$
\begin{gathered}
\nu_{i}(\theta)=\min _{x}\left\{\sum_{j=1}^{n}\left(c_{i j}-s_{j}(\theta)\right) x_{i j} \mid \sum_{j=1}^{n} x_{i j}\right. \\
\left.\leqq a_{i}, 0 \leqq x_{i j} \leqq \theta_{j}\right\} \quad \ldots \ldots \ldots \ldots \ldots \ldots \ldots \ldots
\end{gathered}
$$

とする。この $\theta$ の関数 $\nu_{i}(\theta)$ は，次のようにして求め ることができる。

まず，ラグランジュ乗数 $s_{j}(\theta)$ は，双対変数の性質 から次の上うに考えることができる。

$$
s_{j}(\theta)=\psi_{j p} \quad\left(\theta \in \Psi_{p} ; p=1, \cdots, P\right) \cdots
$$

電学論C, 110 巻 10 号, 平成 2 年
また，次の式が成立する。

$$
\Psi_{1} \cup \cdots \cup \Psi_{p}=D
$$

領域 $\Psi_{p}$ を考之, $c_{i j}(\theta)=c_{i j}-\phi_{j p}$ と招き, $\bar{c}_{i j}, j=$ $1, \cdots, n$ を小さい傾に並び換え，

$$
\bar{C}_{i j_{1}} \leqq \cdots \leqq \bar{C}_{i j q} \leqq 0<\bar{C}_{i j q+1} \leqq \cdots \leqq \bar{C}_{i j_{n}}
$$

とし，この問題の最適解 $\bar{x}_{i j}, j=1, \cdots, n$ を考える。

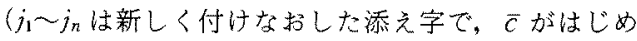
て0を超えるときの添え字を $j_{q+1}$ とする)ここで，

$$
\begin{aligned}
& \Omega_{p_{t}}=\left\{\theta \mid \sum_{g=1}^{t-1} \theta_{j_{g}} \leqq a_{i}<\sum_{g=1}^{t} \theta_{j_{\theta}}\right\} \\
& \Omega_{p, n+1}=\left\{\theta \mid \sum_{g=1}^{n} \theta_{j_{\theta}} \leqq a_{i}\right\} \ldots \ldots . .
\end{aligned}
$$

で定義される領域 $\Omega_{p t}(t=1, \cdots, n+1)$ を考える。

また，目的関数の罗小化を考えると $x_{i j}$ 怙非負よ D， $\bar{c}_{i j} \leqq 00$ ときは，できるだけ $x_{i j}$ を増やし， $\bar{c}_{i j}$ $>0$ のときは $x_{i j}$ を0にすればよい。すなおち， $t \leqq q$ のとき,

$$
\bar{x}_{i j_{g}}=\left\{\begin{array}{l}
\theta_{j_{g}}(g=1, \cdots, t-1) \\
a_{i}-\sum_{u=1}^{t-1} \theta_{j_{g}} \quad(g=t) \\
0 \quad(g=t+1, \cdots, n)
\end{array}\right.
$$

一方, $t>q$ のとき,

$$
\begin{aligned}
& \bar{x}_{i j_{g}}=\left\{\begin{array}{ll}
\theta_{j_{\theta}} & (g=1, \cdots, q) \\
0 & (g=q+1, \cdots, n)
\end{array} \cdots \cdots \cdots \cdots \cdots(59)\right. \\
& \nu_{i}(\theta)=\sum_{j=1}^{n} \bar{c}_{i j}(\theta) \bar{x}_{i j}(\theta) \\
& \left(\theta \in \Omega_{p t} ; p=1, \cdots, P ; t=1, \cdots, n+1\right)
\end{aligned}
$$

と計算できる。

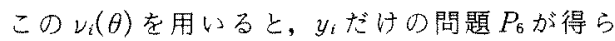
れる。

問題 $P_{6}$ :

$$
\begin{aligned}
\min _{y} \sum_{i=1}^{m}\left\{\int_{D}\left(\nu_{i}(\theta)+f_{i}\right) F(\theta)\right. \\
\left.\quad \times d \theta_{1} \cdots d \theta_{n}\right\} y_{i}+\int_{D}\left\{\sum_{j=1}^{n} s_{j}(\theta) b_{j}(\theta)\right. \\
\quad \times F(\theta)\} d \theta_{1} \cdots d \theta_{n} \cdots \ldots \ldots \ldots \ldots \ldots \ldots \\
\text { s. t. } \sum_{i=1}^{m} a_{i} y_{i} \geqq S(\alpha) \\
\quad y_{i} \in\{0,1\} \quad(i=1, \cdots, m) \quad \cdots \cdots \cdots \cdots \cdots
\end{aligned}
$$

目的関数の第 1 項の $y_{i}$ の倸数は, 定数であり，良 とする。第 2 項は，次式が成立するため問題 $P_{6}$ の下 界值を計算できる。 


$$
\begin{aligned}
& \int_{D}\left\{\sum_{j=1}^{n} s_{j}(\theta) b_{j}(\theta) F(\theta)\right\} d \theta_{1} \cdots d \theta_{n} \\
& \geqq \int_{D^{\prime \prime}}\left\{\sum_{j=1}^{n} s_{j}(\theta) \theta_{j} F(\theta)\right\} d \theta_{1} \cdots d \theta_{n} \\
& \ldots \ldots \cdots \cdots \cdots \cdots \cdots \cdots \cdots \cdots \cdots \cdots \cdots \cdots \cdots \cdots \cdots \cdots \\
& D^{\prime \prime}=\left\{\theta \mid \theta \in D, \sum_{j=1}^{n} \theta_{j} \leqq S(\alpha)\right\} \quad \cdots \cdots \cdots \cdots
\end{aligned}
$$

以上より, 問題 $P_{5}$ は, 次の問題 $P_{7}$ を解くことに帰 着できる。

問題 $P_{7}$ :

$$
\begin{aligned}
& \min _{y} \sum_{i=1}^{m} \xi_{i} y_{i} \quad \cdots \cdots \cdots \cdots \cdots \\
& \text { s.t. } \sum_{i=1}^{m} a_{i} y_{i} \geqq S(\alpha) \cdots \cdots \cdots \\
& y_{i} \in\{0,1\} \quad(i=1, \cdots, m)
\end{aligned}
$$

(66) 式の制約をラグランジュ緩和した問題の上界值 は，簡単に得ることができる。このため，ナップサッ 問題 $P_{7}$ を厳密に解が゙に問題の下界值を得る方法 も考えられる。

$$
z(\lambda, y)=\sum_{i=1}^{m} \xi_{i} y_{i}+\lambda\left(S(\alpha)-\sum_{i=1}^{m} a_{i} y_{i}\right)
$$

として $\max _{\lambda \geqq 0} \min _{y} z(\lambda, y)$ を考えればよい。

問題 $P_{7}$ を解くことにより得た下界值で見切ること ができなければ，分枝する必要がある。

問題 $P$ 亿に扔いて $\xi$ が求まれば，非常に簡单な問題で ある。こ机使って分枝変数の選択，分枝の方向を決 定する。分枝によっでまだ固定されていない変数の中 で，0または1へ固定した下界值の差が最も大きい変 数を分枝変数とする。

〈3.5〉不確定需要を考慮した施設配置問題の解法 アルゴリズム本章で述べた部分問題を用い，分枝 限定法に基づくアルゴリズムを提案する。ここで， $\mathrm{CP}$ (Current Problem) は, 分枝限定木上の処理対 象のノードにおける問題である。

アルゴリズム $A$ :

step 1：暫定值 $z^{*}=\infty$, 分枝候補リス卜を初期化 し, CP 系分枝状態の問題とし, $\mathrm{CP} の$ 下界値二0とする。

step 2：S( $\alpha)$ を計算する。

step 3：CPの下界值が暫定值以上ならば step 12 へ。

step 4: 連続緩和問題 $P_{2}$ 省解いて下界值を強化 する。

step 5：CPの下界値が暫定値以上ならば step 12 step 6：step 4 の解が整数解ならば，暫定值を更新 し, step 12 へ。

step 7：ラグランジュ緩和問題により下界值の強化 を行う。

step 7.1：元問題の需要に関する制約条件に対し て, ラグランジュ緩和し，問題 $P_{5}$ を作 成する。

step 7.2： step 4 の双対変数を問題 $P_{5}$ のラグラン ジュ轱数とする。

step 7.3:（65)式の $\xi$ を求める。

step 7.4：問題 $P_{6}$ を解き, 強化した下界値を得る。 step 8：CP の下界值が暫定值以上ならば step 12 へ。

step 9：固定されていない変数がなければ, step 12 へ。

step 10 : 問題 $P_{2}$ の解で, 小数である変数の中から 0 および 1 八の固定の下界値の差が最も大 きい変数を選択し，その変数の 0 および1 への固定で得られる下界值が大きい順に分 枝候補りス卜に入れる。また，この下界值 計算に上って, 得られる下界值を発生した 二つの分枝ノードの下界值とする。

各変数の 0 扔よび 1 の下界値計算中に, 0への固定により害行不可能になる变数は 1 に固定する。

またある変数において， 0,1 への固 定において小さい下界値が暫定值を超える ならば CP 見切り, step 12 へ。

step 11 : 分枝候補リスト = 終了。最適値 $z^{*}$ 。

step 12 : 分枝候補リストの中から LIFOルールで $\mathrm{CP}$ を選択する。

step 13 : step 3 へ。

\section{4. 需要の確率密度関数}

本章では, 需要の確率密度関数について少し触 れる。

本論文では，需要の分布を仮定し，確率密度関数を 与えなければならない。現実問題において, 需要の分 布は，両側有界の份布関数であり，一般に上く用いら れる正規分布は適用できない。両側が有界で，いろい ろな形を仮定できる分布にベータ分布がある。1パラ メータのベータ分布の確率密度関数は, 次の上うに なる。

$$
F(\theta)=\frac{\theta^{p-1}(1-\theta)^{q-1}}{B(p, q)}
$$


本論文で提案するアルゴリズムを数值皘分なしで解 くためには, 1 パラメータの場合, 確率密度関数 $F(\theta), \theta F(\theta)$ の不定積分が簡単に求まる関数であれ ば，解くのに非常に楽である。アルゴリズムの途中 て，用いる数値皘分の計算時間は，全体の演算速度に 非常に関係するものと考えられる。

(69)式で与えられるべータ分布も，一般の $p, q$ に 対しては不定積分が求まらず，不完全べー夕関数比 $I_{\theta}(p, q)$ を必要とする $\left(I_{\theta}(p+1, q)\right.$ なども必要)。

複数パラメータの場合, 問題 $P_{3}$ の $\theta^{\prime}$ に対する確率 密度関数 $F\left(\theta^{\prime}\right)$ が必要である。パラメータ $\theta^{\prime}$ 間には ほとんど相関がないと考えると確率密度関数は，次の ようになる。

$$
F\left(\theta^{\prime}\right)=\frac{\theta_{1}^{p_{1}-1}\left(1-\theta_{1}\right)^{q_{1}-1} \cdots \theta_{n}^{p_{n^{\prime}-1}}\left(1-\theta_{n^{\prime}}\right)^{q_{n^{\prime}-1}}}{B\left(p_{1}, q_{1}\right) \cdots B\left(p_{n}^{\prime}, q_{n}^{\prime}\right)}
$$

\section{5. 数 值 実 験}

本章では, 本論文で提案した解法アルゴリズムの有 効性を示すために行った数值実験の結果を示す。

プログラム言語は, Fortran 77 であり, 数值実験

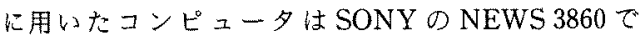
ある。

問題は，次の条件で作成した。

（1）建設候補地数は， $5 ， 10 ， 15$ の 3 種類。

(2) 需要地数は, 10,2002 種類。

（3）需要量の分布を表す確率変数の数 $n^{\prime}=2,3$ 。

表 1 数値実験結果（10 間の平均）

Table 1. Computational results (average for ten problems).

\begin{tabular}{|c|c|c|c|c|c|c|}
\hline $\begin{array}{l}\text { No. of } \\
\text { Random } \\
\text { Variables }\end{array}$ & $\begin{array}{l}\text { No. of } \\
\text { Facilities }\end{array}$ & $\begin{array}{l}\text { No. of } \\
\text { Customers }\end{array}$ & $\begin{array}{l}\text { CPU } \\
\text { Time } \\
\text { (s) }\end{array}$ & $\begin{array}{l}\text { No. of } \\
\text { Nodes }\end{array}$ & $\begin{array}{l}\text { No. } \\
\text { Problem } \\
P_{2} \text { Solved }\end{array}$ & $\begin{array}{l}\text { No. } \\
\text { Problem } \\
P_{s} \text { Solved }\end{array}$ \\
\hline \multirow{6}{*}{2} & \multirow{2}{*}{5} & 10 & 1.2 & 28.2 & $2,227.5$ & 28.9 \\
\hline & & 20 & 3.8 & 29.1 & $2,465.1$ & 30.5 \\
\hline & \multirow{2}{*}{10} & 10 & 1.5 & 19.8 & $1,960.2$ & 64.8 \\
\hline & & 20 & 4.0 & 34.6 & $2,356.2$ & 153.2 \\
\hline & \multirow{2}{*}{15} & 10 & 2.2 & 23.7 & $2,293.5$ & 82.3 \\
\hline & & 20 & 9.6 & 43.5 & $4,306.5$ & 245.9 \\
\hline \multirow{6}{*}{3} & \multirow{2}{*}{5} & 10 & 3.9 & 9.3 & $6,593,4$ & 22.1 \\
\hline & & 20 & 10.9 & 9.5 & $6,893.1$ & 28.1 \\
\hline & \multirow{2}{*}{10} & 10 & 6.4 & 9.3 & $8,591.4$ & 38.0 \\
\hline & & 20 & 23.9 & 20.2 & $13,986.0$ & 103.9 \\
\hline & & 10 & 23.5 & 29.6 & $26,862.0$ & 121.3 \\
\hline & & 20 & 147.3 & 73.7 & $69,530.4$ & 442.3 \\
\hline
\end{tabular}

（4）総需要を満たす確率 $\alpha=0.95$ 。

（5）重皘分の計算点数 $=10$ 。

（6）供給量，需要量の割合は，約半分の建設候補 地に施設が建設されるようにランダムに作成。

（7）建設固定費，輸送費の関係怯，最適解见おい て，建設固定費の占める割合が約 $30 \%$ になるように ランダムに作成。

（8）輸送費 $c_{i j}$ 快，建設候補地と需要地を 2 次元 平面上にランダムにプロットし，現実問題を表現でき るように，三角不等式を満たす。

表 1 に以上の条件で行った数值実験の結果を示す。 演算時間, 分枝回数, 下界值計算のための問題 $P_{2}$ を 解くために用いた輸送問題を解いた回数，下界值強 化，分枝変数選択問題 $P_{5}$ の回数の 10 間平均を示卞。

需要量の分布を表す確率変数の個数は 2 および $3 て ゙$ ある。本数值実験では，計算方式 2 をいているた め，輸送問題を解く回数が多くなっているが，再最適 化の手法を用いているため, 高速に解かれている。

問題の規模が大きくなれば，演算時間がかかる傾向 があるが，問題構造にも大きく影響される。これは， 分枝限定法の性質を受けたものであり，本実験から も，本アルゴリズムの演算時間が，問題規模だけでな く，問題楧造に影響されることがわかる。

\section{6. 終りに}

本論文では，より現実的な問題を解くために，需要 量に分布を仮定した施設配置問題のモデル化を行っ た。本問題怯, 混合整数計画問題に確率変数が含まれ る複稚な問題である。しかし，本問題から導かれる解 は，パラメトリック施設配置問題(7)の解よりも非常に 有用な情報が得られる。これは, パラメトリック施設 配置問題では，パラメータの領域別に建設方法が求め られるため，需要量の不確実性を考慮できないからで ある。

本アルゴリズムの特徵は, 下界值の強化部分にあ り，ナップザック問題に帰着して解く部分にあると考 えている。この強化がパラメータ全領域で整数変数を 固定するという条件を考慮している。

提案したアルゴリズムでは，既往の研究にみられる ような問題の縮小（釘付けテスト）などについては， 触狆ていない。不確定需要を考慮した施設配置問題に 対して、このような研究が望まれる。

(平成 2 年 7 月 9 日受付) 


\section{文献}

(1) N. Christofides \& J. E. Beasley: "Extensions to a Lagran gean Relaxation Approach For The Capacitated Ware house Location Problem", European J. Operational Res. 12. 19 (1983)

(2) Z. Drezner \& G. O. Wesolowsky: "The Expected Value of Perfect Information in Facility Location". Operations Research, 28, 395 (1980)

（3）今野・鈴木：「整数計画法と組合せ最適化」, ORライブラリ 一, 第 7 巻（昭 62）日科技連

(4) R. M. Nauss: "Parametric Integer Programing (1979), University of Missuri Press

(5) F. Rado: "The Euclidean Multifacility Location Problem", Operations Research, 36, 485 (1988)

（6）桧垣・本多・西田：「多重選択制約付施設配置問題と乞の 解法」, 日本才ペレーションズリサーチ学会 1989 年度春期研 究発表会予稿集

（7）大竹・西田：「パラメトリック施設配置問題の一解法」, 計測 自動制御学論. 21 , No. 8 (昭 60 )

（8） 伊理・今野：数理計画法の応用〜理論編（昭 57）産業図晴

(9) J. V. Jucker \& R. C. Carlson: "The Simple Plant-Location Problem Under Uncertainty". Operations Research, 24. 1045 (1976)

(10) R. Hassin \& E. Zemel: "Probabilistic Analysis of The Capacitated Transportation Problem", Mathematics Oper ations Research, 13, 80 (1988)

(11) J. E. Hodder: "Financial Market Approaches To Facility Location Under Uncertainty". Operations Research, 32. 1374 (1984)

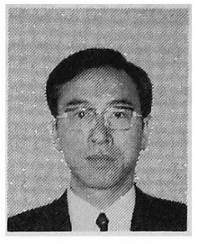

\section{西 田 直 矩 (正員)}

昭和 18 年 10 月 12 日生。 47 年, 東京工業大学大学院博士課程修了。 現在, 東京理科大学工学部経営工学 科教授。この間, 50 年アメリカ Auburn 大学, 51 年 Carnegie-Mellon 大学客員準教 授。システム制御工学の研究に従事 (工学博士)。

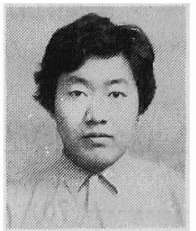

桧 垣 正 浩（非会員）

昭和 39 年 2 月 19 日生。昭和 63 年, 東京理科大学大学院修士課程工 学研究科経営工学専攻修了。現在, 同大学院博士課程に在籍。現実問題 に存在する施設配置問題，配送路決定問題などを中心 とする最適化理論を研究中。

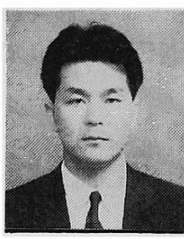

馬㴊透（非会員）

昭和 39 年 10 月 22 日生。平成元 年, 東京理科大学大学院修士課程工 学研究科経営工学専攻修了。現在, 四国日本ソフトウェア(株) 勤務。 